\title{
Horses, Fish and Humans Interspecies Relationships in the Nordic Bronze Age
}

\author{
Jacob Kveiborg ${ }^{1} \odot$, Laura Ahlqvist ${ }^{2} \odot \&$ Helle Vandkilde ${ }^{3}$
}

In this article, we identify and discuss Nordic Bronze Age interspecies relationships through a relational approach that is open to ontologies that differ from our own. Drawing on bronze objects, faunal remains and rock art recovered from a multitude of Nordic Bronze Age sites (I700-500 BC), we outline the complex evolution and interactions of significant socioeconomic and cosmological elements such as the horse, the sun, the warrior, the sea and fish, and their relationships to life and death. We suggest that these elements may be seen as interconnected parts of an entangled whole, which represents a specific Nordic Bronze Age cosmology, which developed between 1600 and I 400 BC, and combined local, archaic world views and foreign influences.

Keywords: human-animal-thing relationships, relational approach, ontology, cosmology

\footnotetext{
${ }^{1}$ Department of Archaeological Science and Conservation, Moesgaard Museum jkv@moesgaardmuseum.dk

2 Department of Archaeology and Heritage Studies, Aarhus University laura.ahlqvist@cas.au.dk

${ }^{3}$ Department of Archaeology and Heritage Studies, Aarhus University farkhv@cas.au.dk
}

This is an Open Access article distributed under the terms of the Creative Commons 4.0 International licence (CC BY 4.0) (http://creativecommons.org/licenses/by/4.0/), which permits unrestricted use, distribution, and reproduction in any medium, provided the original work is properly cited. 


\section{Introduction}

It is well-established that ships and horses were vitally important to people in southern Scandinavia during the Bronze Age (circa I700-500 BC) (Kaul 1998, 2004; Kveiborg 2019; Ling 2008; Ling et al. 2018). Not only did ships and horses serve as means of transportation, they were also powerful symbols that characterised an upper societal rung, and acted as liminal elements that explained complex cosmological phenomena, such as the sun's journey across the sky and the transport of the dead from one world to another (Kaul I998, 2004, 2005; Armstrong Oma 20I3; Johannsen 20I4; Kveiborg 20I9). This is evident in the rich archaeological record of rock carvings as well as ornamented bronze objects and horse bones and teeth from burials and votive depositions from the Nordic Bronze Age (Table I). Furthermore, horse and ship seem to entangle and hybridise in ways that make them inseparable and transcend strict naturalist categorisation (Kaul 1998). Recently, similar suggestions were made regarding horses and birds and birds and humans, and much research lends credibility to the idea that metamorphoses, hybrid creatures and liminal transfers were essential to Nordic Bronze Age life worlds to a much greater extent than they are today (Goldhahn 2019). Numerous finds, such as the elaborate multispecies Viksø
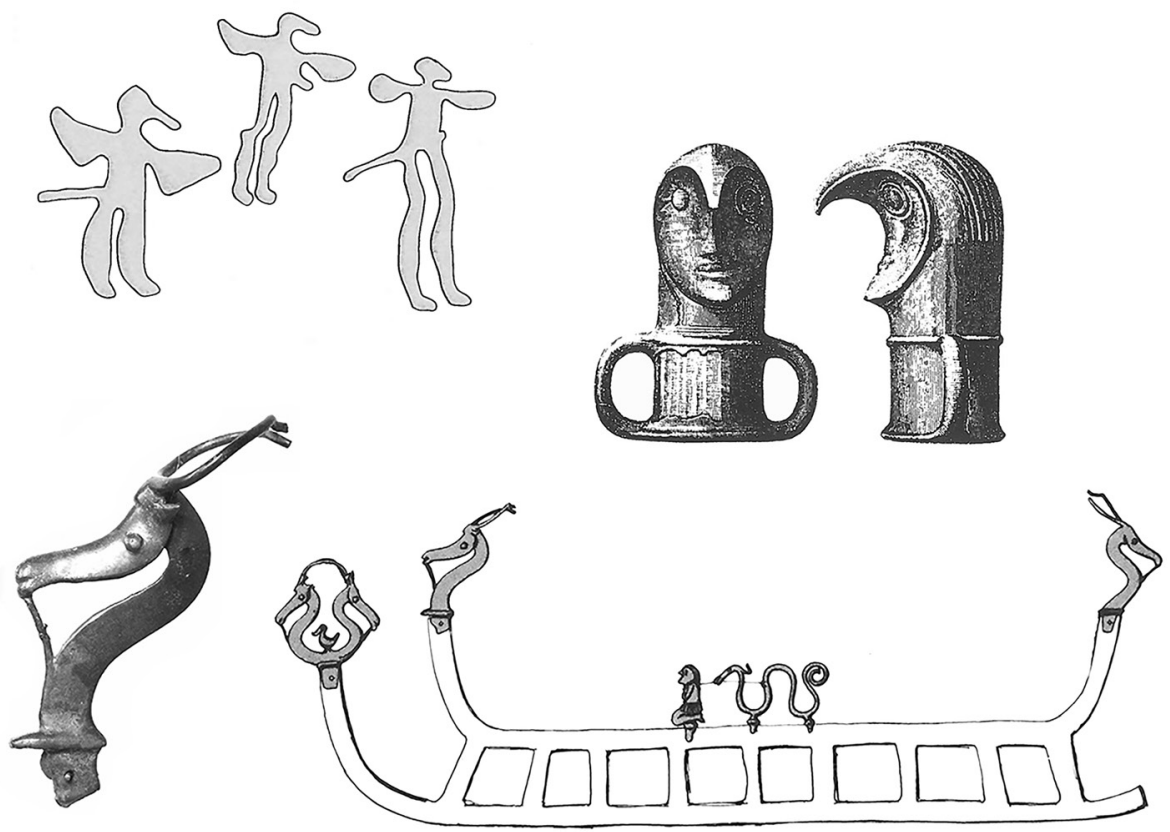

Figure I. Bird-men, snake-horses and horned horses. Various examples of hybrid beings in Nordic Bronze Age metalwork and rock art (after Coles \& Bengtsson 1990; Glob 1962: Kaul 1998; Montelius I9I7). 
helmets and the curious assemblages of animal bones, twigs, stones, etc. associated with the sorceress's graves in Maglehøj and Hvidegård, clearly indicate this (Boye I889; Kaul I998: I6-20; Vandkilde 20I3; Ahlqvist \& Vandkilde 20I8; Goldhahn 20I9; Figure I).

The presence of presumed sorceresses or shamans, and animistic elements such as metamorphosis suggest that the strict ontological separation of nature and culture, humans and animals, body and mind, which prevails in modern Western ontologies, may differ from what was probably the norm in many past societies, including those of the Bronze Age (see Holbraad 2009; Alberti \& Marshall 2009; Hedeager 20I0, 20II; Watts ed. 20I3; Goldhahn 20I9). Accordingly, our analytical framework must be receptive to social contexts that are embedded in ontologies that diverge from our own. If we accept that different units (such as ship and sea, horse and heaven, ship and horse), in specific situations or more generally, could have been perceived as ontologically similar, and thus interchangeable, it implies a change in perspective - from 'either/or' to 'both/and'. Therefore, this article argues that examining the manifestations of how humans, animals and things related to each other may offer alternative insights into the minds, beliefs and associated practices of past people.

The risk of the foregoing approach is of merely substituting one orthodoxy for another. However, a relational analytical approach need not imply that all related entities in a given context should be attributed equal importance. In a comparable vein, proponents of the so-called symmetrical archaeology realise that some relationships are more spectacular or nodal than others (e.g. Olsen \& Witmore 2015:I92). Additionally, different ontological modes may be at work in specific relationships or on specific occasions: sometimes a stone is just a stone, whereas on other occasions it may be imbued with life and a deeper ontological meaning (Harris \& Robb 20I 2:670). Furthermore, it is imperative to stress that the dynamics of various relationships may change over time, smoothly or abruptly, especially in the sense that history may take a direction that prompts new worldviews, through new inventions and technologies, or through altered strategies to legitimise new social regimes. Finally, humans may regard themselves as being in control of relationships in some domains, and less so or not at all in others. Such a relational approach to the Bronze Age complements more top-down analyses of social and economic change (e.g. Kristiansen \& Larsson 2005; Ling et al. 2018; Bech et al. ed. 2018).

This survey is not restricted to horses and ships, although they form its backbone. To embrace the variety of meanings associated with these two entities, it also considers associated phenomena, such as fish and sea, and sword and warrior. The survey consists of three interlocked case studies. Using a bottom-up approach, we begin by outlining the various archae- 
ological evidence that signifies the introduction of the horse to southern Scandinavia. This allows us to track social relations among horse, sun and warrior, a trilogy that materialises around $\mathrm{I} 600-\mathrm{I} 500 \mathrm{BC}$. However, possibly not until NBA II (circa I500-I300 BC) do the horse and its links to the sun become integrated in an elaborate belief system (Kveiborg 2019:255). Alongside the horse, a striking preoccupation with fish, ships, water, waves

Table I. Table summarising archaeological horse- and fish-related material culture discussed in this article with the addition of further supporting evidence. The quantity of each category of evidence varies from a few isolated occurrences but most are representative of a larger corpus of material.

\begin{tabular}{|c|c|c|}
\hline \multicolumn{3}{|c|}{ Early NBA (c. $1600-1100$ BC) } \\
\hline & Horse & Fish/sea \\
\hline $\begin{array}{l}\text { Objects and } \\
\text { contexts }\end{array}$ & $\begin{array}{l}\text { Unique specimens or serial occurrences: } \\
\text { Antler cheek-pieces (hoard) (Østrup) } \\
\text { Stimuli/goads (burials) (e.g. Strandtved, } \\
\text { Buddinge) } \\
\text { Horse-headed belt hooks (burials) (e.g. } \\
\text { Kirke-Værløse, Abekås) } \\
\text { Wheeled Sun Horse (hoard) (Trundholm) } \\
\text { Twin horse figurines (hoard) (Tågaborg) } \\
\text { Horsehead handled razors (burials) (e.g. } \\
\text { Abekås) }\end{array}$ & $\begin{array}{l}\text { Unique specimens or serial occurrences: } \\
\text { Scimitars (e.g. Rørby) } \\
\text { Eelgrass, water-rolled pebbles, sea } \\
\text { urchins (burials) (e.g. Maglehøj) } \\
\text { Watering mounds (burials) (e.g. Skelhøj) } \\
\text { Bronze fish hooks (hoards and burials) (e.g. } \\
\text { Valsømagle I, Strandtved, Karlstrup) }\end{array}$ \\
\hline Faunal remains & $\begin{array}{l}\text { A number of: } \\
\text { Settlements various bones (e.g. Bjerre, } \\
\text { Apalle) } \\
\text { Burials objects (e.g. Maglehøj (horse teeth) } \\
\text { Wetlands (e.g. Hindby Kärr, Tollense) }\end{array}$ & $\begin{array}{l}\text { Few fish, numerous marine shells: } \\
\text { Settlements (e.g. Apalle) } \\
\text { Burials (e.g. Vejleby, Hvidegaarden) }\end{array}$ \\
\hline $\begin{array}{l}\text { Pictorial } \\
\text { evidence }\end{array}$ & $\begin{array}{l}\text { Serial occurrences: } \\
\text { Charioteers (e.g. Kivik, Villfara) } \\
\text { Horses (e.g. Sagaholm) } \\
\text { Chariots (e.g. Fränarp) }\end{array}$ & $\begin{array}{l}\text { A number of or plentiful: } \\
\text { Ships, wavy bands (objects) (e.g. Rørby) } \\
\text { Fish (spearheads) (Valsømagle II, Haga) } \\
\text { Fish and ships (burials) (Kivik) } \\
\text { Ships (numerous rock carvings) }\end{array}$ \\
\hline $\begin{array}{l}\text { Cosmological } \\
\text { developments } \\
\text { interpreted }\end{array}$ & $\begin{array}{l}\text { - c. } 1600 \text { BC, in NBA IB, a tripartite } \\
\text { cosmology is in the making stimulated by } \\
\text { novel warrior ideals } \\
\text { - c. } 1500 \text { BC, in NBA II, the full interspecies } \\
\text { relation horse-human-sun is materialised in } \\
\text { belt hooks and in the Trundholm Sun Chariot }\end{array}$ & $\begin{array}{l}\text { Sea/water materialises as the medium } \\
\text { connecting the three worlds of the Universe. } \\
\text { Sea/water is linked to death and perceived } \\
\text { as an avenue to the underworld?, with Fish } \\
\text { and ship as associates }\end{array}$ \\
\hline References & $\begin{array}{l}\text { Aner \& Kersten 1973:123, plate 75, 53-54, } \\
\text { 1977:196-197, plate 139; Bech et al. 2018; } \\
\text { Benecke \& Dräger 2014; Ericson et al. 2003; } \\
\text { Fredell 2003:191 fig. 5.14; Goldhahn 1999, } \\
\text { 2013:477-488; Holst 2015:56; Johannsen } \\
\text { 2010; Kveiborg 2019; Kristiansen \& } \\
\text { Larsson 2005; Müller 1903; Nilsson 2007; } \\
\text { Nyegaard 1996; Oldeberg 1974:104-107; } \\
\text { Schnittger 1925:88-89; Thrane 1965:65 } \\
\text { fig. 7; Vandkilde 2014:612 fig. 4, 617 fig. 7; } \\
\text { Willroth 1997:488-492 fig. 4-6 }\end{array}$ & $\begin{array}{l}\text { Aner \& Kersten 1973:53-55; 1976:130, } \\
\text { plates 78, 80, 1977:36, 146; Ericsson et al. } \\
\text { 2003; Holst et al. 2015, 293-306; Kaul 1998, } \\
\text { 2004; Kristiansen \& Larsson 2005; Montelius } \\
\text { 1917:52; Vandkilde 2014 fig. 4, 10, } 11\end{array}$ \\
\hline
\end{tabular}




\begin{tabular}{|c|c|c|}
\hline \multicolumn{3}{|c|}{ LATE NBA (c. 1100-500 BC) } \\
\hline & Horse & Fish/sea \\
\hline $\begin{array}{l}\text { Objects and } \\
\text { contexts }\end{array}$ & $\begin{array}{l}\text { A number of or plentiful: } \\
\text { Deposited horse figurines (e.g. Fårdal, } \\
\text { Mariesminde) } \\
\text { Horse gear (hoards, burials) (e.g. Bækkedal, } \\
\text { Annelöv) } \\
\text { Ritual objects (e.g. Viksø) } \\
\text { Wagons (e.g. Lusehøj, Egemose) }\end{array}$ & $\begin{array}{l}\text { Few: } \\
\text { Fish hooks (burials) (e.g. Store Karlsminde) } \\
\text { Fish hooks (settlements) (Kornerup) }\end{array}$ \\
\hline Faunal remains & $\begin{array}{l}\text { Numerous: } \\
\text { Settlements (e.g. Hötofta, Kirkebjerget) } \\
\text { Wetlands (e.g. Torresta) } \\
\text { Burials (hair dress of horse hair) (Hvilshøj) }\end{array}$ & $\begin{array}{l}\text { Numerous fish and marine shells: } \\
\text { Settlements (e.g., Højbjerggård, Sandeplan) } \\
\text { Burials (shells) (e.g. Bakkebjerg) }\end{array}$ \\
\hline $\begin{array}{l}\text { Pictorial } \\
\text { evidence }\end{array}$ & $\begin{array}{l}\text { Numerous: } \\
\text { Sun Horses (razors, rockart) (e.g. Neder } \\
\text { Hvolris) } \\
\text { Horse-hybrids on bronze objects, especially } \\
\text { razors (e.g. Veerst, Stenderup) } \\
\text { Wagons and Chariots (rock art) (Bottna, } \\
\text { Aspeberget) } \\
\text { Mounted warriors (rock art) (e.g. Järrestad) }\end{array}$ & $\begin{array}{l}\text { Few: } \\
\text { Fish (belt bowls, razors, rock art) (e.g. } \\
\text { Kulsbjerg, Torslev, Kallerby Tanum 402:1) } \\
\text { Scenes of fishing (rock art) (e.g. Ödsmål) } \\
\text { Plentiful: } \\
\text { Ships (rock art, objects) }\end{array}$ \\
\hline $\begin{array}{l}\text { Cosmological } \\
\text { developments } \\
\text { interpreted }\end{array}$ & $\begin{array}{l}\text { - Horse is fully integrated in the tripartite } \\
\text { cosmological realm } \\
\text { - Final NBA, the role of the horse seems to } \\
\text { change } \\
\text { - Iron Age, the horse is merely a riding } \\
\text { animal for war }\end{array}$ & $\begin{array}{l}\text { Sea/water is still linked to death and } \\
\text { underworld } \\
\text { Fish are liminal hybrid creatures that are } \\
\text { condensed in fish hooks. Food taboo? } \\
\text { Fishing is layered into the cosmological } \\
\text { cycle. }\end{array}$ \\
\hline References & $\begin{array}{l}\text { Ahlqvist \& Vandkilde 2018; Althin 1945: } \\
\text { plate 60; Kaul } 1998 \text { cat. no. 243, 313, 316; } \\
\text { Kveiborg 2019; Lepiksaar 1969; Lomborg } \\
\text { 1963; Nyegaard 1996; Jacob-Friesen 1969 } \\
\text { fig. 3-5; Fredengren 2015; Johannsen 2010; } \\
\text { Sarauw 2016; Thrane 1984 fig. 86-87; } \\
\text { Vandkilde 2013:166 fig. 1; Varberg 2013 }\end{array}$ & $\begin{array}{l}\text { Appel \& Pantmann 2013, 110ff; Aner \& } \\
\text { Kersten 1973:7; Becker 1941; Berntsson } \\
\text { 2005, 105-121; Broholm 1949:273 fig. 103; } \\
\text { Cardell 1997; Fredsjö et al. 1956; Kaul 1998 } \\
\text { cat. no. 176, 270; Nyegaard 1996; Pantmann } \\
\text { \& Enghoff 2011 }\end{array}$ \\
\hline
\end{tabular}

and the sea in human practices and minds seems to be in place at the onset of the Nordic Bronze Age (circa I600 BC) (Vandkilde 20I4). Thus, in the second case study, we explore how sea- and fish-related matters were associated with the beliefs and actions of Bronze Age male warriors. These interrelationships seem to outline a relational cosmology that addresses life and death, while showcasing the lifestyles of an upper class of warriors and their kin. The sea and associated phenomena are further unfolded in the third and final case study. Here we question the interpretation of fish hooks as merely indicative of fishing in an economic sense, and examine the importance of these objects as grave goods in urn burials, where they may be understood within a complex set of relationships with shared ontological origins that obliterate the distinctions between fish and humans, life and 
death, and so on, as we understand them today. By presenting these three different yet interlinked case studies, we employ a relational approach to propose a new, alternative interpretation of how animal-human-thing relationships and associated cosmologies evolved and manifested throughout the Nordic Bronze Age.

\section{Horse, sun and human: a social and cosmological trinity}

A large body of work has already been dedicated to Nordic Bronze Age symbolism and iconography, including the sun and the horse (Kaul I998, 2004, 20I3, 20I8a, 20I8b). This scholarship makes the relationships between horse, sun and human an obvious point of departure for improving our understanding of Nordic Bronze Age ontology. The onset of the Nordic Bronze Age was heavily influenced by strong foreign inspirations (Vandkilde 20I4), and similarly the horse and horse gear, including the chariot, had distant origins. Originating in the Eurasian Steppe zone, the horse, horsemanship and charioteering transferred into the Near East and temperate Europe through the Caucasus, the Mediterranean and the Carpathian Basin (Hüttel I98I; Boroffka 1998; Penner 1998; Kristiansen \& Larsson 2005; Anthony 2007; Cunliffe 2015).

Contesting the interpretation of the bronze rods from the Jutland Gallemose hoard (circa I900 BC) as chariot parts (Kveiborg 20I9; cf. Randsborg I992, 20IO), we recognise the earliest evidence of the domestic horse in Scandinavia as dating to the beginning of the Bronze Age (circa I600 BC), documented by finds of horse tack and horse representations (Kveiborg 20I9). Early Bronze Age bridle cheek-pieces made of antler are known from Østrup Bymark (Roskilde, Zealand) (Thrane 1965:65 fig. 7, I999; Vandkilde 20I4:6I7 fig. 7). The Østrup pair shares its ornamental style with NBA IB (circa I600-I500 BC) metalwork and with equivalent Carpathian, Steppe and Aegean cheek-pieces adorned with wavy bands and sometimes spirals (Hüttel I98I; Boroffka I998; Penner 1998; Thrane I999; Kristiansen \& Larsson 2005; David 2007; Vandkilde 20I4:6I8-6I9 figs $8-9)$. This indirect evidence of the bridled horse accords with NBA IB warrior burials in Strandtved (Bovense, Funen) and Buddinge (Gladsakse, Zealand). Both graves include an elongated, pointed bronze cane interpretable as a goad (or stimulus) alongside rich weaponry. Goads are associated with charioteering and are used to urge horses to increase speed (e.g. Willroth I997:488-492 fig. 4-6; Kaul \& Randsborg 2008; Vandkilde 20I4:6I 2 fig. 4). Through the presence of the goad as the relational insignia of the charioteer, other rich NBA IB-early NBA II (circa I550-I 450 BC), male 


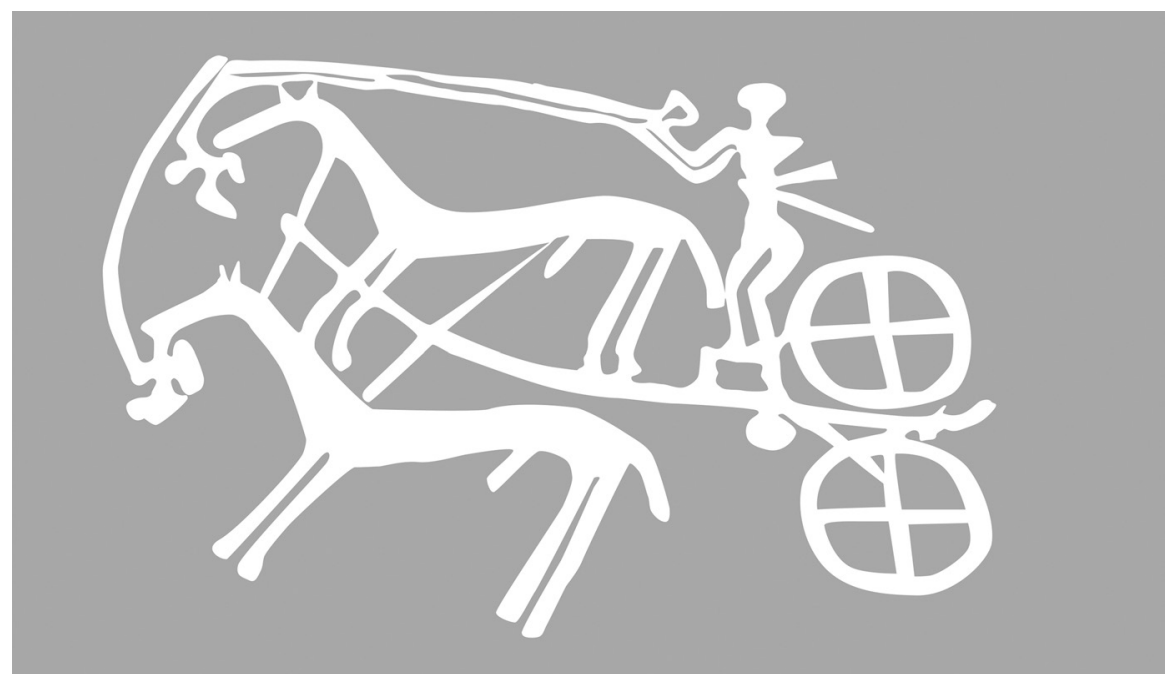

Figure 2. Detail of the harnessed horses and the charioteer depicted on stone slab number 7 in the Kivik burial chamber, Sweden. Note how the horse's bridle is accentuated. Also note the sword and goad in the charioteer's belt (based on rubbing made by Dietrich Evers; by permission of the Swedish Rock Art Research Archives. ID: 3009; Bertilsson et al. 20I7).

graves attest to the significance of the chariot as well (Willroth I997; Kaul \& Randsborg 2008).

A probable goad and a sword also appear in the belt of the charioteer depicted on one of the stone slabs from the Kivik tomb, which dates to roughly the same time as some of the above-mentioned warrior burials (Goldhahn 2013:477-488; Kristiansen \& Larsson 2005:I89-I93, I97; Vandkilde 2020; Figure 2). The team of stallions harnessed to the Kivik chariot is distinctly bridled, which reveals knowledge of how to handle horses. This indicates that the horses depicted were not merely imagined creatures of tales and myth, but renderings of real physical beings engaged in intimate human-horse relationships, including charioteering. The Kivik chariot scene has clear counterparts in the Mycenaean culture, as seen on the contemporaneous shaft-grave stelae from Grave Circle A at Mycenae (cf. Karo I933: Taf. V), reinforcing the link between the Aegean and the Nordic Bronze Ages. Similar chariot scenes also occur in Scandinavian rock carvings, which may well belong to the same period (Kaul 2004:293-298; Johannsen 20I0). In summary, the detailed presentation of stallions in a local elite burial setting and its wider context suggests that social ambition and warriorhood played a central role in the introduction, adoption and early social uses of the horse, or vice versa. In contrast, a cosmological link between horse, sun and human was not yet expressed in material culture at this early stage (Kveiborg 2019). 

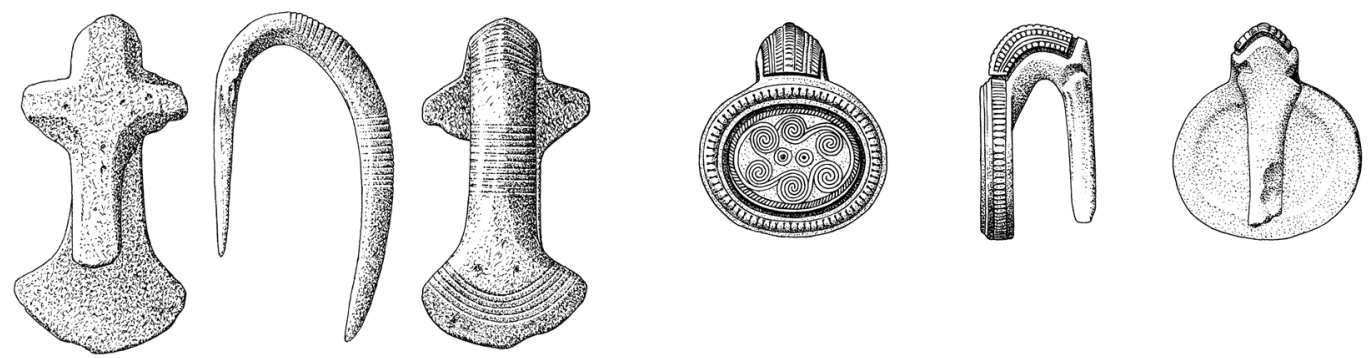

Figure 3. Horse-headed belt hooks (circa I600-I 400 BC). Early ones (left) have a straight arm with no reference to the sun, whereas later ones (right) carry a spiral-decorated sundisc on the horse's back (after Aner \& Kersten 1973: nos. 364, 45 I taf. 75, 95).

The often overlooked category of horse-headed belt hooks covers the same time span as the above mentioned early manifestations (circa I600I $400 \mathrm{BC}$ ), and may illustrate the beginning of a close bond between horse and human, which eventually developed into a cosmologically endorsed relationship. It may exemplify the formation of intimate and entangled relationships and interactions between humans and non-humans in general, materialising in hybrid beings that challenge a modern Western worldview (see Armstrong Oma 20I8; Goldhahn 2019 for other examples; Figure 3).

The earliest belt hooks - with a straight and often decorated arm - may be interpreted as a horse head and mane, and thus belong to the aforementioned exclusive group of rich NBA IB/early NBA II warrior burials, emphasising a particular relationship among horse, chariot and warrior in this early phase (Figure 3). At some point in the fifteenth century BC (NBA II), the horse-headed belt hook developed into a representation of the sunhorse through the addition of an often spiral-decorated and gold-plated end disc interpreted as an image of the sun (Figure 3) (Fredell 2003:19I fig. 5.I 4; Holst 2015:56; Ahlqvist \& Vandkilde 20I8 fig. 5; Kveiborg 20I9:252 fig. I3). The warrior burial at Kirke Værløse, near Copenhagen, epitomises this new integration of the sun into the horse-human relationship. Besides weapons and other male objects, the burial holds a sun-horse-adorned belt hook, and a fragment of a goad (Aner \& Kersten I973:I23-I25, plate 75).

As illustrated, the associations of early Bronze Age horses and humanhorse relationships are male and warlike in character, establishing a clear link to other European elite milieus through a shared pan-European ideology of warriorhood. Initially, the horse may have been more connected to an elite identity than to a cosmology centred on the sun. This interpretation is consistent with the rather infrequent depiction of horses and the elite status of the male charioteer in NBA IB-II. It also accords with the observation that horses do not appear as obvious cosmological symbols on bronzes and in rock carvings until mature NBA II (circa I400-I300 
$\mathrm{BC}$ ), when composite representations of horses and suns are frequent (Kaul 2004:293, 27I-320; Skoglund 20I6:28-29). Prominent examples are the sun-horse wagon from Trundholm and, in all likelihood, the Tågaborg hoard, with a presumed, but lost, sun-disc and the two amber-eyed bronze stallions (Müller 1903; Schnittger 1925:88-89).

Most of our knowledge of animals and human-animal relationships in the early Bronze Age relies on indirect evidence rather than bones, as the number of known settlements from this period with animal bone assemblages preserved are few (Nyegaard 1996; Kveiborg 2019:230, tab. 2). The available data, however, suggests a socially motivated development involving the horse as a prestigious animal, and a stepwise transformation of the horse during the fifteenth century $\mathrm{BC}$ into a cosmological being manifesting a sun-oriented cosmology already in place prior to this development.

Consistently with the foregoing, the alternate horse-ship hybrid also does not fully emerge until the late NBA II, which emphasises the significance of these early phases in the formation of the Nordic Bronze Age cosmology (Kaul I998, 2004:290, 2013).

Based on the available record, the ideal of the charioteer seemed to thrive only during the early phases of the Bronze Age, and it had almost disappeared by the middle of NBA II (Willroth I997:488). Although representations of horses in the early Bronze Age record are well-attested, their number and ontological complexity escalated during the late Bronze Age (circa II00-500 BC), which is evident from rock carvings (Malmer I98I; Johannsen 20IO), bronze objects (Kaul I998, 2004) and ritual hoards (von Brunn I98I; Varberg 20I3). In addition, a considerable number of animal bone assemblages are available from late Bronze Age settlements (e.g. Lepiksaar 1969; Nyegaard 1993, 1996; Ericson et al. 2003; Kveiborg 20I9, table 2), which indicate that something changed in the horse-related practices around this time. Given the close links among various spheres of life, as outlined above, it is suggested that these changes accompanied ontological developments. Suggestively, the increasingly complex uses of the horse already evident by the early Bronze Age developed into even more fluid interspecies relationships in the late Bronze Age (Ahlqvist \& Vandkilde 20I8; Kveiborg 20I9).

\section{Matters of life and death: the sea, fish and ships in the Bronze Age}

As discussed above, the archaeological record indicates that during the Bronze Age, society became preoccupied with horses and horsemanship to the extent that the horse was intertwined with various aspects of life 
and death. Possibly, this facilitated an ongoing metamorphosis of various matters within an animistic ontology, blurring our naturalist categorisation of the world and challenging our worldview. Similarly, the enhanced connection to the sea, through the introduction of oceangoing longboats and long-distance waterborne journeys and trade, may have affected the beliefs and worldview of Bronze Age people during the NBA IB, extending the ontological meanings of ship and sea in similar ways as was the case for the horse, as manifested in thousands of ships in rock art and on bronzes (Kaul I998; Ling 2008). It has been suggested that this manifestation is evident in the NBA IB scimitar, the shape of which resembles a ship (Kaul I998:73-86; Vandkilde 20I4). Together with the decoration of a longship on one of the Rørby scimitars (Vandkilde 2014:620 fig. I0), this showcases the interconnectedness in people's minds and practices outlined above, not only of the sea and the ship, but of warrior and weapon, and in how all these elements were being incorporated into what may be described as a shared ontological scheme, the origins of which may be traced to the Carpathian Basin, where a similar devotion to depicting fish, water, ships and the sun flourished (Vandkilde 20I4).

The ship drawn on one of the Rørby scimitars is powered by 36 oarsmen, who move the vessel towards the wave-shaped sword tip, and flowing water is indicated by wavy bands framing the panel (Vandkilde 20I 4:620 fig. IO). Suggesting a transitional role of water and the sea, it is intriguing to translate the ornamentation of the Rørby scimitars and the objects themselves into a relational linkage between the Bronze Age cosmology and real-world adventures at sea. How far did such associations extend into real life? Perilous sea voyages to 'the beyond' may well have held a dual meaning as real-world maritime visits to foreign lands and the travel between worlds undertaken posthumously. Sea and water also occur as various configurations of wavy bands on the scimitars, and on the Fårdrup, Sögel and Hajdúsámson-Apa weaponry in general, further accentuating the importance of waterborne journeys, fatal dangers and the unknown (e.g. Vandkilde 20I4:6I6 fig. 6).

Associations between the sea (water) and burial (death) are further evident in the numerous burial mounds of the early Bronze Age through the widespread use of eelgrass and beach pebbles as lining for wooden coffins, just as marine shells and fossilised sea urchins are frequent (Aner \& Kersten 1973, I976, I979; Holst et al. 2015:297-300). In addition, water played a prominent role in a group of mounds dated to NBA II, through what is believed to be an intentional 'watering' of the mounds to reduce or postpone the natural decomposition and disintegration of the dead, as recently discussed by Holst et al. (2015:295-296). Although the exact distribution of seashells in graves has not been fully surveyed, the use of marine shells in burials is especially evident in the Wadden Sea region of north-western 

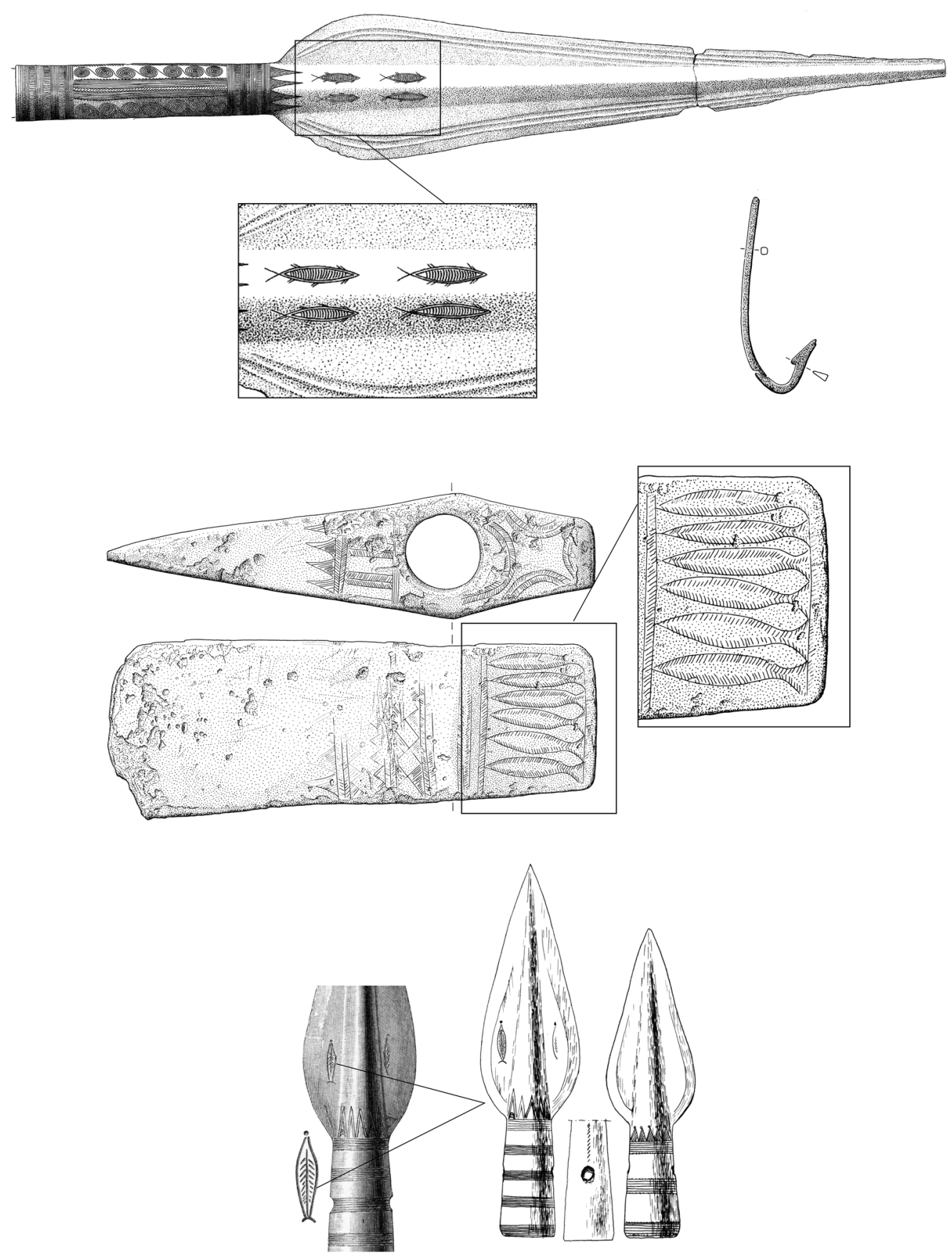

Figure 4. Examples of Early Nordic Bronze Age weapons with fish images and a fish hook. From Valsømagle, Uhe and Haga (Aner \& Kersten I976: nos. I097-I098, I990: no. 4452; Oldeberg 1974: no. 21I7). 
Germany and on Zealand (Aner \& Kersten 1973, 1976, 1979), whereas the use of eelgrass predominates on Zealand (Aner \& Kersten 1973, 1976). In contrast, the intentional watering of the mound is a Jutland phenomenon (Holst et al. 2015:299 fig. 2). Drawing a relational link between the importance of the sea and water as givers and takers of life, the regional differences in how sea/water-burial/death links are presented may be interpreted as different manifestations of a shared theme linking sea and water to burials and death.

Burial customs that link the sea and death continued in the late Bronze Age, following the adoption of the cremation burial custom (Holst et al. 2015:298). This is evident through fish hooks as grave goods, amongst other finds (see below). Based on the available evidence (Table I), the interrelationships of fish hooks, fish and warriors were quite apparent by the beginning of the Bronze Age. In three cases, fish are depicted on weapons from NBA IB ritual wetland depositions (Figure 4). On the huge spearhead from the Valsømagle II hoard (Ringsted, Zealand), eight fish swim towards the deadly point of the blade, and the spearhead itself faintly resembles the outline of a fish (Vandkilde 20I4:622 fig. II). Similar fish appear on a Valsømagle-type spearhead from Haga (Gotland, Sweden) and a series of twelve fish decorate a Fårdrup-type shaft-hole axe from Uhe (Vejle, Jutland) (Montelius 1917:52; Aner \& Kersten 1990:67; Vandkilde 20I4:622 fig. II).

A limited number of early fish hooks may be added to the foregoing examples (Figure 5). One large fish hook occurs in the Valsømagle I hoard (Ringsted, Zealand): this object may seem strangely out of place in the context of rich weaponry, but probably attests to the links among the maritime realm, weapons and warriors (Aner \& Kersten 1976: plates 78-79). In NBA II, these links were still active, with fish hooks appearing in rich warrior burials at Annisse (Frederiksborg, Zealand) and Karlstrup (Copenhagen, Zealand) (Aner \& Kersten I973: plates I, I09). To these we may add a NBA II bog hoard at Hønsinge (Holbæk, Zealand) which includes an oversized fish hook accompanied by two spiral-decorated disc plates belonging to the female attire (Aner \& Kersten 1976: plate 42). Similarly, in the late Bronze Age, fish are present on a female belt bowl from NBA V (circa 900-700 BC) (Broholm I949:273 fig. I03). Together with the Hønsinge find as well as the prevalence of wave-band ornamentation on these presumed female objects (Sprockhoff \& Höckmann I979), this suggests that the sea-linked cosmology pertained to both the male and female spheres. Nevertheless, and akin to the early Bronze Age horse-warrior pairing, depictions of fish are predominantly associated with male attributes, especially as part of the cosmological imagery on razor blades (e.g. Kaul I998: cat. nos. I76, 205,270 ). Thus, the razors vividly demonstrate the complex relationships among various entities, including the male warrior, the sun and the sea, 


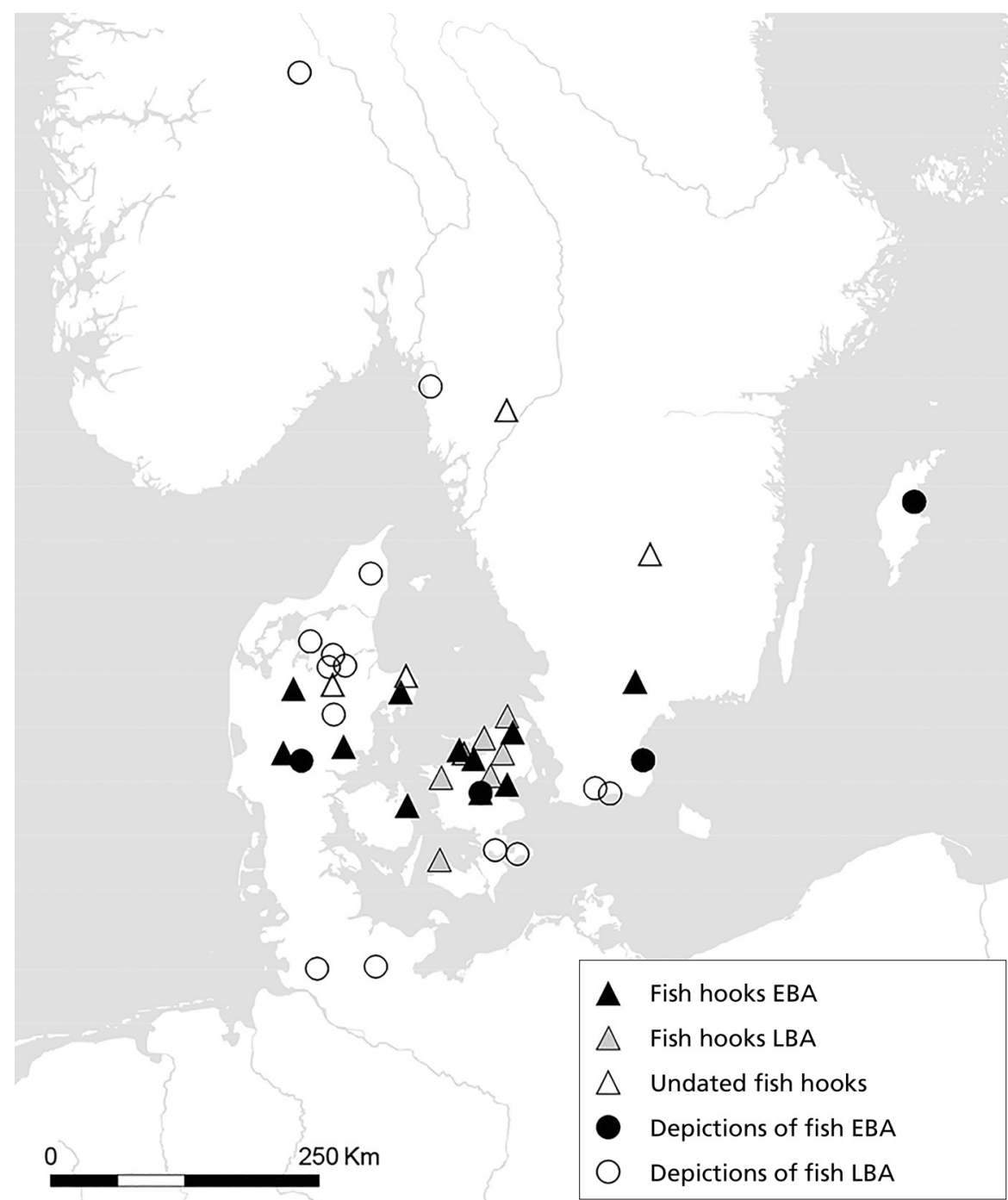

Figure 5. The distribution of fish hooks and fish images from the early and late Nordic Bronze Age, respectively (graphics by Casper Skaaning Andersen, Moesgaard Museum).

horses, fish and ships, which seem to be the backbone of Bronze Age cosmology (Kaul I998).

This short survey of ships, fish, sea and other marine elements reveals the importance of the maritime domain throughout the Nordic Bronze Age, in contexts and forms that may appear separate, but in the Bronze Age were probably perceived as interwoven to at least some degree. Furthermore, there seem to be connections among all these marine elements, the perceived order of the cosmos and human death, as discussed above. Suggestively, 
this is further materialised on the Kivik cist in the imagery of a large fish and sailing ships on the panels, in a manner recalling the Rørby scimitar (Kristiansen and Larsson 2005:267-268 fig. II7). Maritime relationships and connotations unfold even more impressively through the thousands of ships on rock panels and bronze objects from throughout the Bronze Age (Kaul I998; Ling 2008). One the one hand these ships accentuate the importance of seafaring and travel to distant worlds, and on the other, the key roles of the ship and the sea in narratives and cosmology intended to address life as well as death, and as a tool through which the passage of time and the movement of the sun could be explained.

\section{Fish, fishhooks and fishing in the late Nordic Bronze Age}

As argued above, the link between the sea and death evolved already in the early Bronze Age. In the present section we will show how this relationship became concretised in the late Bronze Age. From this point in time, the number of preserved fish bone assemblages increase, enabling a relational approach to fish and fishing that goes beyond the symbolic and iconographic realms. Zooarchaeological analyses show that the fish are almost exclusively gadiformes - predominantly Atlantic cod (Gadus morhua) (e.g. Nyegaard 1996; Cardell I997; Berntsson 2005:I05-I I0; Jonsson 2005; Pantmann \& Enghoff 20II). The analyses further corroborate that the gadids caught during the late Bronze Age were larger than those caught during the preceding Mesolithic and Neolithic periods. Together, the presence of fish hooks and increased numbers of bones from large fish in settlements may suggest a shift from fishing at stationary coastal fish weirs to specialised deep water angling from boats, using hooks on a line, as seen in a number of Swedish rock art panels (Berntsson 2005; Pantmann \& Enghoff 20II; Figure 6).

The intimate relationship between the sea and humans - including ontological links between the sea and death - during the late Bronze Age is further accentuated by the presence of fish hooks in a number of graves (Figure 5). Traditionally, fish hooks in graves have been interpreted as an indication of the profession of the deceased (e.g. Becker I94I; Appel \& Pantmann 20I3). However, inspired by Fahlander (20I4), we cannot uncritically assume that fish hooks (or other implements) in burials were meant to symbolise an occupation, any more than we may be certain that the human bones in these burials are those of fishermen. As argued above, the sea, fish, fish symbolism and fish hooks may be interpreted as a natural extension of the Bronze Age cosmological scheme where death and re- 


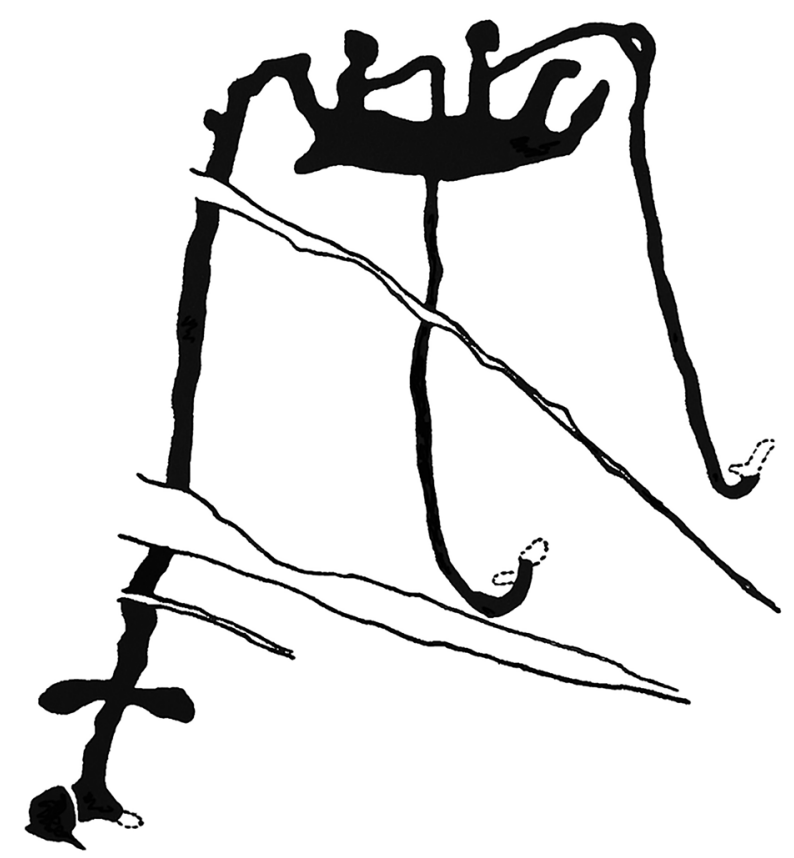

Figure 6. 'Game fishing'. Rock art from Ödsmål in Bohuslän (from Fredsjö et al. I956).

birth/afterlife in another world took centre stage. As such, ships, fish, the sea and fish hooks may have carried otherworldly meanings in a number of extraordinary contexts that in themselves appear both relational and transitional. In a manner of speaking, these forms transcended categorisation and had hybrid qualities. This fits well with Fahlander's argument that fish hooks may be considered hybrid forms (Fahlander 20I4:247). This hybridity is not merely symbolic, but a real condition, the qualities of which lie in its relationships rather than in the objects (see Goldhahn 2019 for a similar perspective).

As Kaul states (1998, 2004), in the late Bronze Age, fish, the sea and ships continued to be associated with death, rebirth and the netherworld, and the eternal journey of the sun. Perhaps the kin of the deceased - through appropriate funerary rituals - saw their deceased relative hybridise with the sea, eventually becoming a fish, a soul of the sea, a liminal being, whereby an eternal afterlife, or rebirth, was attained in fulfilment of the cosmological cycle. This interpretation may easily merge with existing hypotheses that suggest that the dead could be recruited as crew members aboard the sun-ship, provided their relatives met the proper funerary requirements (Kaul 2005:I40).

Suggestively, during the late Bronze Age the relational perception of death and afterworld is also manifest in fishing. A compelling explanation 
of the predominance of large gadiformes has been suggested by Berntsson (2005), who argues that Bronze Age fishing should be interpreted as a prestigious 'big fish hunting' analogous to modern-day game fishing and trophy hunting. Accordingly, what mattered was not the number of fish caught but the size of the fish, and perhaps even the epic effort invested in the venture. Furthermore, deep-sea fishing requires knowledge of the sea and navigation to find the optimal fishing spot. Arguably, just like longdistance journeys at sea, Bronze Age deep-water fishing may thus have been linked to the society's elite (Berntsson 2005:I I 4-I I5). Hunting was (and still is) an important aspect of the aristocratic lifestyle, as a symbolic demonstration of power through which the untamed outside world is subjugated (Shapland 2013). In the Mycenaean world, hunting scenes were a recurrent theme in which semi-divine heroes or the ruling elite were depicted hunting wild or mythological beings. Essentially, the depictions were repetitions of the mythological hunt, which could sometimes serve as a substitute for warfare and/or involve sacrifice. These may also be viewed as transmitting power from the hunted to the hunter, and a restart of the life cycle; that is, a performative interspecies engagement, a statement of social position and a setting for negotiating the perception of otherness (Kristiansen \& Larsson 2005:347; Overton \& Hamilakis 20I3:II4).

At a structural level, several elements of the mythological hunt may be identified in late Bronze Age game fishing. The fish was the hunted, a wild, chthonic, even hybrid being that resided in the uncivilised outside world, which resembled the netherworld. An important part of the mythological hunt was the killing, whether seen as a negotiation between the hunter and the hunted or a display of physical and mental skills (Ingold 2000: 60-76; Shapland 2013). Consuming game and fish further facilitated the transfer of power, and perhaps even the souls of the dead.

Equating the mythological hunt and late Bronze Age game fishing may provide a framework that further explains the strong links between the socially superior warriors and fish during the early Bronze Age (NBA IB-II) (see cases above). They were not simply fishermen in a modern sense. Without doubt these warriors were associated with warfare and power (Vandkilde 20I8), but they may also have been esteemed hunters who, through mythological hunts, were able to connect with their dead companions and relatives, and eventually transform into helpers of the sun in the form of fish, horses or crew members aboard the sun-ship. The mythological hunt was deeply embedded in fishing and in fish consumption and did not have to manifest in highly ritualised acts, except perhaps on special occasions (Mansrud \& Kveiborg submitted). Fishing was multi-layered and integrated into Bronze Age ontology, everyday life, death, and rebirth as part of the cosmological cycle. 


\section{Nordic Bronze Age ontology: closing discussion}

A relational approach to horses and fish can produce alternative perspectives on the intricate networks of humans, animals and things in the Bronze Age which both contradict and complement earlier interpretations (Kaul I998, 2004). An emphasis on interspecies relations, rather than on bounded entities, enables us to explain the formation and nature of the Bronze Age world in ways that break with the conformity of a naturalist perspective that forces us to interpret material culture in specific and predetermined ways, leaving no room for the unexpected and the inexplicable.

We have discussed how, in the sixteenth century BC, we see glimpses of select human-animal-object relations adapted to exclusive sociocultural frameworks that broke with the past. There is some weight to the claim that the constructs of shape-shifting and hybrid creatures were not new. Rather, it relied on traditional animistic practices evident in Eurasia's deep past, and in contemporary northern Scandinavian hunter-gatherer societies (e.g. Hultkrantz 1978; Morphy 1989; Bolin 2000; Conneller 2004; Borić 2007; Lindström 20I2; Bradley \& Nimura 20I3; Ahlqvist \& Vandkilde 20I8; Hedeager 20IO, 20II). Apparently, people continued to be tightly connected to their animated past. So, what exactly was new in the Bronze Age?

In NBA IB, local animistic elements and perhaps also a circular, solar logic, were integrated into a new ideology likely imported from abroad (Kristiansen \& Larsson 2005). This coincides with increased mobility and interconnectivity, as evidenced by the spread and consumption of bronzes that characterised the onset of the Nordic Bronze Age. Major elements had, or soon gained, local appeal: certain animals (horses, fish), distinct lifestyles (ideas of supreme warriorhood), and certain things and technologies (such as ships, chariots, swords and spears). This bricolage provided ambitious people - probably travellers - with a comparative advantage in social rivalry, and could - through proper burial rituals - provide a memorable and successful passage from life to death. This nascent version of the cosmology of the Nordic Bronze Age evolved over time and diffused into non-elite societal segments throughout the Bronze Age.

The exclusivity of early Bronze Age cosmology is striking, and the attention paid to particular warriors and elaborate weaponry emphasises that power and wealth were important drivers of its introduction. Furthermore, although few in number, the human-animal-thing hybrids found in NBA IB are very distinct, with clear messages, whereas other elements are quite subtle, as though the target group was initially rather small and consisted of the initiated only. Some of the elements were transmitted and added simultaneously, whereas others evolved locally. The fish was probably incorporated at the beginning of NBA IB (circa I600 BC), as part of a cos- 
mological scheme, together with scimitars, spearheads and so on, whereas the horse was introduced as a symbol of power, from which it evolved locally into a distinct and complex cosmological symbol during the following century (circa $\mathrm{I} 500 \mathrm{BC}$ ) and beyond. The delayed incorporation of the horse into the cosmology, compared to that of the fish, may be ascribed to a general unfamiliarity - both physical and mental - with the horse as a newly-introduced animal (Kveiborg 20I9). Not until a general trust between horses and humans had been established did the horse take centre stage.

In consideration of the importance of the horse and the fish to Bronze Age peoples, a careful proposition regarding Bronze Age beliefs has been put forward: is it possible that corporeal distinctions between humans and horses may have faded in liminal spaces? Especially the apparent links between horse (upperworld/day) and fish (netherworld/night) as part of a cosmological scheme that seemingly materialised during the late Bronze Age attests to the transferential role of both horse and fish as boundary-crossers. Perhaps the presence of horses and fish in human graves (albeit only indirectly inferred through relational counterparts such as belt and fish hooks and goads, or as iconography (on razors and belt bowls) should be viewed in this light. In liminal spaces - in fulfilment of the cosmological cycle humans, horses and other creatures became transcendent beings that elude present-day classification (Armstrong Oma 20I3).

\section{Conclusions}

This article has argued that examining how humans, animals and things relate, merge and transform on specific occasions and in specific contexts offers an analytical framework that is receptive to social contexts embedded in ontologies, including that of the Nordic Bronze Age, deviating from our own. We may reasonably expect that the diverse contexts, forms and materials of human-animal relationships depended on how the world was organised mentally and physically, whether represented as bodies, bones or teeth, in animalistic razor handles or as hybrid beings in rock art. The intimacy with which the various relationships unfolded may also have been of key importance. The relational approach applied in this article acknowledges that humans shape animals and their worlds, and also that worlds are co-shaped. We have presented three case studies to show how horses and fish were inextricably linked to human life and death in the Bronze Age. This intimacy was not just physical; it permeated all aspects of life, including the spiritual and cosmological levels, as exemplified by the studies discussed above. These intimate relationships relied on a dynamic and multidirectional perception of a world in which humans and animals were 
ontologically related, and where souls and bodies could be reborn, transformed, or hybridised with things and other beings, including horses and fish, on specific occasions and at special places. We argue that these results could not have been obtained without a relational, multi-vocal approach, which allows us to further reveal the complexity and dynamics of the entities involved in the formation and development of the Bronze Age world.

\section{Acknowledgements}

This co-authored article springs from J. Kveiborg's $\mathrm{PhD}$ thesis, The Nordic Bronze Age Horse: Studies of human-horse relationships in a long-term perspective (Graduate School at the Faculty of Arts, Aarhus University). The thesis was co-financed by Aarhus University and Moesgaard Museum.

\section{References}

Ahlqvist, L. \& Vandkilde, H. 20I8. Hybrid Beasts of the Nordic Bronze Age. Danish Journal of Archaeology. Vol. 7(2) pp. I80-I94.

Alberti, B. \& Marshall, Y. 2009. Animating Archaeology: Local Theories and Conceptually Open-ended Methodologies. Cambridge Archaeological Journal. Vol. I9(3) pp. 344-356.

Althin, C.-A. I945. Studien zu den bronzezeitlichen Felszeichnungen von Skåne. Lund: Gleerup.

Aner, E. \& Kersten, K. 1973. Die Funde der älteren Bronzezeit des nordischen Kreises in Dänemark, Schleswig-Holstein und Niedersachsen. Vol. I. Frederiksborg og Københavns amt. Neumünster: Wachholz Verlag.

Aner, E. \& Kersten, K. 1976. Die Funde der älteren Bronzezeit des nordischen Kreises in Dänemark, Schleswig-Holstein und Niedersachsen. Vol. 2. Holbak, Sorø og Prastø Amter. Neumünster: Wachholz Verlag.

Aner, E. \& Kersten, K. 1979. Die Funde der älteren Bronzezeit des nordischen Kreises in Dänemark, Schleswig-Holstein und Niedersachsen. Vol. 5. Copenhagen. Neumünster: Wachholz Verlag.

Aner, E. \& Kersten, K. 1990. Die Funde der älteren Bronzezeit des nordischen Kreises in Dänemark, Schleswig-Holstein und Niedersachsen. Vol. 9. Vejle Amt. Neumünster: Wachholz Verlag.

Anthony, D. 2007. The Horse, the Wheel and Language: How Bronze-Age Riders from the Eurasian Steppes Shaped the Modern World. Princeton: Princeton University Press.

Appel, L. \& Pantmann, P. 20I3. Udnyttelse af havets ressourcer i bronzealderen. Nordsjællandske gravfund i nyt lys. In: Boddum, S., Mikkelsen, M. \& Terkildsen, N. (eds). Dødekulten i yngre bronzealders lokale kulturlandskab: Seminarrapport fra seminariet 'Dødekulten I yngre bronzeladers locale kulturlandskab' afholdt $i$ Viborg, 8. marts 2OI2. Yngre bronzealders kulturlandskab Vol. 3, pp. IO3-II5. Viborg: Viborg Museum/Holstebro Museum. 
Armstrong Oma, K. 20I3. Bronze Age Horse: Beyond Dualist Exploitations. In: Bergerbrant, S. \& Sabatini, S. (eds). Conterpoint: Essays in Archaeology and Heritage Studies in Honour of Professor Kristian Kristiansen. BAR International Series BAR S2508, pp. I4I-I46. Oxford: Archaeopress.

Armstrong Oma, K. 20I8. The Sheep People: The Ontology of Making Lives, Building Homes and Forging Herds in Early Bronze Age Norway. Sheffield, UK/Bristol, CT: Equinox Publishing Ltd.

Bech, J.-H., Eriksen, B.V. \& Kristiansen, K. (eds.) 20I8. Bronze Age Settlement and LandUse in Thy, Northwest Denmark. Vol. I-II. Aarhus: Museum Thy/Jutland Archaeological Society.

Becker, C.J. I94I. En begravelsesplads hørende til et nordsjællandsk fiskerleje fra den yngre bronzealder. Nationalmuseets arbejdsmark. Vol. I94I pp. 33-38.

Benecke, N. \& Dräger, J. 20I4. Ergebnisse der archäozoologischen Untersuchungen. In: Jantzen, D., Orschiedt, J., Piek, J. \& Terberger, T. (eds). Tod im Tollensetal: Forsungen $z u$ den Hinterlassenschaften eines bronzezeitlichen Gewaltkonfliktes in MecklenburgVorpommern. Teil I: Die Forshung bis 20I I, pp. 233-238. Beiträge zur Ur- und Frühgeschichte Mecklenburg-Vorpommern 50. Schwerin: Landesamt für Kultur und Denkmalpflege Mecklenburg-Vorpommern.

Berntsson, A. 2005. Två män i en båt: Om människans relation till havet i bronsåldern. Institute of Archaeology, University of Lund. Report Series No. 93. Lund: Lund Unversity.

Bertilsson, U., Ling, J., Bertilsson, C., Potter, R. \& Horn, C. 20I7. The Kivik tomb: Bredarör enters into the Digital Arena - Documented with OSL, SfM and RTI. In: Bergerbrant, S. \& Wessman, A. (eds). New perspectives on the Bronze Age: Proceedings of the I3th Nordic Bronze Age Symposium held in Gothenburg 9th to I3th June 2015, pp. 289-305. Oxford: Archaeopress.

Bolin, H. 2000. Animal Magic: The Mythological Significance of Elks, Boats and Humans in North Swedish Rock Art. Journal of Material Culture. Vol. 5(2) pp. I53-I76.

Borić, D. 2007. Images of animality: Hybrid Bodies and Mimesis in Early Prehistoric Art. In: Renfrew, C. \& Morley, I. (eds), Image and Imagination: A Global Prehistory of Figurative Representation, pp. 89-I05. Cambridge: The McDonald Institute for Archaeological Research.

Boroffka, N. I998. Bronze- und früheisenzeitliche Geweihtresenknebel aus Rumänien und ihre Beziehungen. Eurasia Antiqua. Zeitschrift für Archäologie Eurasiens. Vol. 4 pp. $8 \mathrm{I}-\mathrm{I} 35$.

Boye, V. I889. Maglehøi-Fundet. Aarbøger for Nordisk Oldkyndighed og Historie. Vol. I889 pp. 3I7-340.

Bradley, R. \& Nimura, C. 20I3. The Earth, the Sky and the Water's Edge: Changing Beliefs in the Earlier Prehistory of Northern Europe. World Archaeology. Vol. 45(I) pp. I2-26.

Broholm, H.C. 1949. Danmarks bronzealder. Vol. IV. København: Arnold Busck.

Brunn, W.A. von I98ז. Eine Deutung spätbronzezeitlicher Hortfunde zwischen Elbe und Weichsel. Bericht der römisch-germanischen Kommission. Vol. 60(I980) pp. 9I-I50.

Cardell, A. 1997. Fishbones from a Bronze Age Kitchenmidden in Southern Sweden. Anthropozoologica. Vol. 25-26 pp. 785-788.

Coles, J.M. \& Bengtsson, L. I990. Images of the Past: A Guide to the Rock Carvings and Other Ancient Monuments of Northern Bohuslän. Bohuslän: Hällristningsmuseet.

Conneller, C. 2004. Becoming Deer: Corporeal Transformations at Star Carr. Archaeological Dialogues. Vol. II(I) pp. 37-56. 
Cunliffe, B. 2015. By Steppe, Desert, and Ocean: The Birth of Eurasia. Oxford: Oxford Univesity Press.

David, W. 2007. Gold and Bone Artefacts as Evidence of Mutual Contact between the Aegean, the Carpathian Basin and Southern Germany in the Second Millennium BC. In: Galanaki, I., Tomas, H., Galanakis, Y. \& Laffineur, R. (eds). Between the Aegean and Baltic seas: Prehistory across borders. Proceedings of the International Conference, Bronze and Early Iron Age Interconnections and Contemporary Developments between the Aegean and the Regions of the Balkan Peninsula, Central and Northern Europe University of Zagreb, I I-I 4 April 2005. Aegaeum 27 (2007) pp. 4II-420. Liege.

Ericson, P., Kjellberg, A.-S., Åkermark Kraft, A. \& Wigh, B. 2003. Osteologisk analys av djurbensmaterialet. In: Ullén, I., Bronsåldersboplatsen vis Apalle i Uppland: Arkeologi på väg - undersökningar för EI 8. Riksantikvaämbetet UV Uppsala Rapport 1997:64, pp. 243-3I7. Uppsala: Riksantikvarieämbetet.

Fahlander, F. 20I4. Djur och människor: Posthumanistiska perspektiv på yngre järnålders gravar. In: Alexandersson, H., Andreeff, A. \& Bünz, A. (eds). Med hjärta och hjärna: En vänbok till Elisabeth Arwill-Nordbladh. GOTARC series A. Gothenburg Archaeological Studies Vol. 5, pp. 237-250. Gothenburg: University of Gothenburg.

Fredell, Å. 2003. Bildbroar. Figurativ bildkommunikation av ideology och kosmologiunder sydskandinavisk bronsålder och førromersk järnålder. GOTARC. Serie B. Gothenburg Archaeological Thesis no. 25. Gothenburg: University of Gothenburg.

Fredengren, C. 2015. Water Politics: Wet Deposition of Human and Animal Remains in Uppland, Sweden. Fornvännen. Vol. I I I pp. I6I-183.

Fredsjö, Å., Janson, S. \& Moberg, C.-A. 1956. Hällristningar i Sverige. Stockholm: Forum.

Fyllingen, H. 2006. Society and the Structure of Violence: A Story Told by Middle Bronze Age Human Remains. In: Otto, T., Thrane, H. \& Vandkilde H. (eds). Warfare and Society. Archaeological and Social Anthropological Perspectives, pp. 319-329. Aarhus: Aarhus University Press.

Glob, P.V. 1962. Kultbåde fra Danmarks Bronzealder. Kuml. Vol. I961 pp. 9-I8.

Goldhahn, J. 1999. Sagaholm: Hällristningar och gravritual. Studia Archaeologica Universitatis Umensis Ir. Umeå: Umeå University.

Goldhahn, J. 20I3. Bredarör på Kivik: En arkeologisk odyssé. Kalmar Studies in Archaeology 9. Simrishamn: Linnéuniversitetet/Artes liberals AB.

Goldhahn, J. 2019. Birds in the Bronze Age: A North European Perspective. Cambridge: Cambridge University Press.

Harris, O.J.T. \& Robb, J. 20I2. Multiple Ontologies and the Problem of the Body in History. American Anthropologist. Vol. I I4(4) pp. 668-679.

Hedeager, L. 20I0. Split Bodies in the Late Iron Age/Viking Age of Scandinavia. In: RebaySalisbury, K., Sørensen, M.L.S. \& Hughes, J. (eds). Body Parts and Bodies Whole, pp. I I I-I I 8. Oxford/Oakville: Oxbow Books.

Hedeager, L. 20I r. Iron Age Myth and Materiality: An Archaeology of Scandinavia AD 400-I000. London/New York: Routledge.

Holbraad, M. 2009. Ontology, Ethnography, Archaeology: An Afterword on the Ontography of Things. Cambridge Archaeological Journal. Vol. I9(3) pp. 43 I-44I.

Holst, M.K. 20I5. Bronze Age Geometry and Cosmology. In: Holst, M.K. \& Rasmussen, M. (eds). Skelhøj and the Bronze Age Barrows of Southern Scandinavia. Vol 2. Barrow Building and Barrow Assemblies, pp. 53-89. Højbjerg: Jutland Archaeological Society.

Holst, M.K., Rasmussen, M. \& Breuning-Madsen, H. 20I5. Intended Preservation? In: Holst, M.K. \& Rasmussen, M. (eds). Skelhøj and the Bronze Age Barrows of Southern 
Scandinavia. Vol 2. Barrow Building and Barrow Assemblies, pp. 293-306. Højbjerg: Jutland Archaeological Society.

Hultkrantz, A. I978. Introduction: Ecological and Phenomenological Aspects of Shamanism. In: Bäckman, L. \& Hultkrantz, Å. (eds). Studies in Lapp Shamanism, pp. 9-35. Stockholm: Almqvist and Wiksell International.

Hüttel, H.G. I98I. Bronzezeitliche Trensen in Mittel- und Osteuropa: Grundzüge ibrer Entwicklung. Prähistorische Bronzefunde Abteilung XVI, Band 2. Münich: C.H. Beck'sche Verlagsbuchhandlung.

Ingold, T. 2000. The Perception of the Environment: Essays on Livelihood, Dwelling and Skill. London/New York: Routledge.

Jacob-Friesen, G. I969. Skjerne und Egemose: Wagenteile südlicher Provenienz in skandinavischen Funden. Acta Archaeologica. Vol. 40 pp. I22-I58.

Johannsen, J.W. 20ro. The Wheeled Vehicles of the Bronze Age on Scandinavian RockCarvings. Acta Archaeologica. Vol. 8I(I) pp. I44-247.

Johannsen, N.N. 20I4. Deus Ex Machina: Technological Experience as a Cognitive Resource in Bronze Age Conceptualizations of Astronomical Phenomena. Journal of Cognition and Culture. Vol. I4 pp. 435-448.

Jonsson, L. 2005. Rapport över inledande osteologisk undersökning. Bo, Morlanda socken, fornlämning 89, Huseby klev. In: Nordqvist, B., En kustboplats med bevara organisk material från äldsta mesolitikum till järnålder. Bohuslän, Morlanda socken, Huseby 2:4 och 3:13, RÄ̈ 89 och 485. UV Väst Rapport 2005:2, pp. 96-IO3. Mölndal: Riksantikvarämbetet.

Karo, G. 1933. Die Schachtgräber von Mykenai. Munich: F. Bruckmann.

Kaul, F. 1998. Ships on Bronzes: A Study in Bronze Age Religion and Iconography. PNM Studies in Archaeology and History 3. Copenhagen: National Museum of Denmark.

Kaul, F. 2004. Bronzealderens religion: Studier af den nordiske bronzealders ikonografi. Copenhagen: Det Kongelige nordiske Oldskriftselskab.

Kaul, F. 2005. Bronze Age Three-partite Cosmologies. Prähistorische Zeitschrift. Vol. $80(\mathrm{I})$ pp. I35-I 48 .

Kaul, F. 20I3. The Nordic Razor and the Mycenaean Lifestyle. Antiquity. Vol. 87 pp. $46 \mathrm{I}-472$.

Kaul, F., 2018a. The Nordic Razor as a Medium of Creativity. In: Sofaer, J. (ed.). Considering Creativity: Creativity, Knowledge and Practice in Bronze Age Europe. Oxford: Archeopress Publishing.

Kaul, F. 20I8b. The One-edged Razor: A vivid Medium of Creativity and Meaning. In: Bender Jørgensen, L., Sofaer, J. \& Sørensen, M.L.S. (eds.). Creativity in the Bronze Age: Understanding Innovation in Pottery, Textile and Metalwork Production, pp. I6I-I76. Cambridge: Cambridge University Press.

Kaul, F. \& Randsborg, K. 2008. Hurtige vogne. Skalk 2008(2) pp. 3-7.

Kristiansen, K. \& Larsson, T.B. 2005. The Rise of Bronze Age Society: Travels, Transmissions and Transformations. Cambridge/New York: Cambridge University Press.

Kveiborg, J. 20I9. Traversing Sky and Earth: The Nordic Bronze Age Horse in a Long-term Perspective. Prähistorische Zeitschrift. Vol. 93(2) pp. 225-264.

Lepiksaar, J. 1969. Knochenfunde aus den Bronzezeitlichen Siedlungen von Hötofta. In: Stjernquist, B. (ed.). Beiträge zum Studium von Bronzezeitlichen Siedlungen, pp. I74207. Acta Archaeological Lundensia Series in 40. No 5. Lund: Lund University. 
Lindstrøm, T.C. 20I 2. 'I am the Walrus': Animal Identities and Merging with Animals Exceptional Experiences? Norwegian Archaeological Review. Vol. 45(2) pp. I5I-I76.

Ling, J. 2008. Elevated Rock Art: Towards a Maritime Understanding of Bronze Age Rock Art in Northern Bohuslän, Sweden. GOTARC. Serie B, Gothenburg Archaeological Thesis 49. Gothenburg: University of Gothenburg.

Ling, J., Earle, T. \& Kristiansen, K. 20I8. Maritime Mode of Production: Raiding and Trading in Seafaring Chiefdoms. Current Anthropology. Vol. 59(5) pp. 488-524.

Lomborg, E. I963. Skrydstrup-frisure fra en brandgrav på Mors. Aarbøger for Nordisk Oldkyndighed og Historie. Vol. I963 pp. $3 \mathrm{I}-49$.

Malmer, M. 198I. A Chronological Study of North European Rock Art. Stockholm: Almqvist and Wiksell International.

Mansrud, A. \& Kveiborg, J. submitted. Deep Time, Deep Ontologies? Human-Fish Relations in a Long-term Perspective. Current Swedish Archaeology.

Morphy, H. I989. On Representing Ancestral Beings. In: Morphy, H. (ed.). Animals into Art, pp. I44-I60. London: Unwin-Hyman.

Montelius, O. I9I7. Minnen från vår Forntid I. Stenåldern och Brosåldern. Stockholm: P.A. Nordstedt/Sönners Förlag.

Müller, S. 1903. Solbilledet fra Trundholm. Nordiske Fortidsminder. Vol. I, pp. 303-325.

Nyegaard, G. I993. Kirkebjerg-bopladsen ved Voldtofte, på SV Fyn, i zoologisk belysning. In: Forsberg, L. \& Larsson, T.B. (eds). Ekonomi och näringsformer inordisk bronsålder. Studia Archaeologica Universitatis Umensis 3, pp. 93-I04. Umeå: Umeå University.

Nyegaard, G. 1996. Faunalevn fra Bronzealder: En zoarkcologisk undersøgelse af sydskandinaviske bopladsfund. Unpublished $\mathrm{PhD}$ thesis. Copenhagen University.

Oldeberg, A. 1974. Die ältere Metalzeit in Schweden I. Stockholm: Kungl. Vitterhets Historie och Antivitets Akademien.

Olsen, B. \& Witmore, C. 20I5. Archaeology, Symmetry and the Ontology of things: A Response to Critics. Archaeological Dialogues. Vol. 22(2) pp. 187-I97.

Overton, N.J. \& Hamilakis, Y. 20I3. A Manifesto for a Social Zooarchaeology: Swans and Other Beings in the Mesolithic. Archaeological Dialogues. Vol. 20(2) pp. II I-I36.

Pantmann, P. \& Enghoff, I.B. 20II. På dybt vand. Skalk 20II(I) pp. I2-I5.

Penner, S. 1998. Schliemanns Schachtgräberrund und der europäische Nordosten: Studien zur Herkunft der frühmykenischen Streitwagenausstattung. Bonn: R. Habelt.

Randsborg, K. I992. Gallemose: A Chariot from the Early Second Millennium BC in Denmark? Acta Archaeologica. Vol. 62 pp. I09-I 22.

Randsborg, K. 20I0. Bronze Age Chariots: From Wheels and Yoke to Bridles, Goad and Double-arm Knob. Acta Archaeologica. Vol. 8I pp. 25 I-269.

Sarauw, T. 20I6. The Late Bronze Age Hoard from Bækkedal, Denmark: New Evidence for the Use of Two-Horse Teams and Bridles. Danish Journal of Archaeology. Vol. 4(I) pp. 3-20.

Schnittger, B. I925. Hälsingborgstrakten under Forntiden. I: Bååth, L.M. (ed.). Hälsingborg historia I, pp. 7I-I06. Hälsingborg: Almqvist and Wiksell.

Shapland, A. 2013. Shifting Horizons and Emerging Ontologies in the Bronze Age Aegean. In: Watts, C. (ed.). Relational Archaeologies: Humans, Animals, Things, pp. 190-208. London/New York: Routledge.

Skoglund, P. 20I6. Rock Art through Time: Scanian Rock Carvings in the Bronze Age and Earliest Iron Age. Oxford/Philadelphia: Oxbow Books. 
Sprockhoff, E. \& Höchmann, O. 1979. Die gegossenen Bronzebecken der jüngeren nordischen Bronzezeit. Mainz: Verlag des Römisch-Germanischen Zentralmuseums.

Thrane, H. 1965. De første broncebidsler i Mellem- og Nordeuropa. Aarbøger for Nordisk Oldkyndighed og Historie. Vol. I963 pp. 50-99.

Thrane, H. 1984. Lusehøj ved Voldtofte: En sydvestfynsk storhøj fra yngre broncealder. Fynske Studier XIII. Odense: Odense Bys Museer.

Thrane, H. 1999. Ridedyret. Skalk. Vol. I999(I) pp. I2-I4.

Vandkilde, H. 20I3. Bronze Age Voyaging and Cosmologies in the Making: The Helmets from Viksø Revisited. In: Bergerbrant, S. \& Sabatini, S. (eds). Counterpoint: Essays in Archaeology and Heritage Studies in Honour of Professor Kristian Kristiansen. B.A.R. International Series 2508, pp. I65-I77. Oxford: Archaeopress.

Vandkilde, H. 20I 4. Breakthrough of the Nordic Bronze Age: Transcultural Warriorhood and a Carpathian Crossroad in the I6th century BCE. European Journal of Archaeology. Vol. I7(4) pp. 602-633.

Vandkilde, H. 2018. Body Aesthetics, Fraternity and Warfare in the long European Bronze Age - postscriptum. In: Horn, C. \& Kristiansen, K. (eds). Warfare in Bronze Age Society, pp. 229-243. Cambridge: Cambridge University Press.

Vandkilde, H. 2020. Amber, Weapons and Circulating Ideas about Leadership at the Threshold to the Middle Bronze Age in Europe. In: Maran, J., Băjenaru, R., Ailincăi, S.-C., Popescu A.-D. \& Hansen, S. (eds). Objects, Ideas and Travelers: Contacts between the Balkans, the Aegean and Western Anatolia during the Bronze and Early Iron Age. Volume to the Memory of Alexandru Vulpe Proceedings of the Conference in Tulcea, IO-I3 November, 2017. Unterreihe zu den Universitätsforschungen zur Prähistorischen Archäologie (UPA) Band 350, pp. 3I-42. Bonn: Verlag Dr. Rudolf Habelt GmbH.

Varberg, J. 20I3. Lady of the Battle and the Horse: On Anthropomorphic Gods and their Cult in Late Bronze Age Scandinavia. In: Bergerbrant, S. \& Sabatini, S. (eds.), Counterpoint: Essays in Archaeology and Heritage Studies in Honour of Professor Kristian Kristiansen. B.A.R. International Series 2508, pp. I47-I57. Oxford: Archaeopress,

Watts, C. (ed.). 20I3. Relational Archaeologies: Humans, Animals, Things. London/New York: Routledge.

Willroth, K.-H. I997. Prunkbeil oder Stoßwaffe, Pfreim oder Tätorwierstift, Tüllengerät oder Triebstachel: Anmerkungen zu einigen Metallobjekten der älteren nordischen Bronzezeit. In: Becker, C., Dunkelmann, M.-L., Metzner-Nebelsick, C., Peter-Röcher, H., Roeder, M. \& Teržan, B. (eds). Chronos: Beiträge zur Prähistorischen Archäologie zwischen Nord-und Südosteuropa. Festschrift für Bernhard Hänsel, pp. 469-495. Espelkamp: Verlag Marie Leidorf GmbH. 